\title{
Rights-based Development: Linking Rights and Participation - Challenges in Thinking and Action
}

\section{Valerie Miller, Lisa VeneKlasen and Cindy Clark*}

\section{Introduction}

Over the last several years, a growing number of development and human rights organisations have begun to critically reflect on the impact of their work. With inequality and poverty deepening in many parts of the world, development organisations have been exploring shifts in their strategies with the aim of better addressing structural, systemic causes of poverty and exclusion. And while human rights organisations celebrate advances in strengthening the international human rights framework, ${ }^{1}$ they also recognise the need to do a better job of ensuring that formal rights are actually realised in people's lives. At this critical time of taking stock, each community - human rights and development - brings different strengths and visions to their work, yet opportunities for substantive dialogue between the two are rare, especially among practitioners. Rights organisations bring their work with governments and the international human rights system on issues of state repression and legal reform, while development organisations offer their experience with grassroots groups and in some cases local governments in promoting participation in economic and social programmes.

These conceptual and strategic questions and shifts have been further shaped and stimulated by the emerging trend known as "rights-based approaches" to development. As development actors have expanded opportunities to engage with governments and multilateral institutions, they are strengthening their policy work and embracing and using the human rights system to lend legitimacy to their claims. At the same time, more human rights organisations are seeking to learn about community development and participation, which they have come to see as critical for engaging people in claiming and exercising rights. It is in this convergence between strands of rights and participation approaches where we see the most potential for "rights-based approaches". Yet, despite its potential and its popularity, confusion abounds as to what rights-based approaches means in practice, what lessons it draws from rights and participatory approaches, and how it relates to questions of power, empowerment and "good governance".

This article shares insights and questions generated by a series of interviews with staff and activists involved in US-based international human rights and development organisations as well as practical experiences over several years with both development and rights groups in numerous countries. The tentative conclusions we draw from this study underscore promising directions and synergies in efforts on rights, participation, governance and citizenship as well as raising important concerns and challenges.

\section{Clarifying meanings and linkages}

More systematic thinking and ongoing dialogue are urgently needed to clarify the meanings of participation and rights and related terms of empowerment and rights-based approaches to development, including their relationships to one another and their implications for practice. This section summarises some of the insights gathered about the meanings of rights and participation and potential links between them.

\subsection{Participation}

Meanings of participation are multiple and range from people participating, by providing information 
to development agencies for better project design to people analysing problems and participating in decision making as genuine protagonists. Much participation work over the recent past has focused on and made gains in enabling communities and groups to analyse their reality and to define and carry out solutions to local development problems. Some programmes that advance participation have helped to increase sensitivities about gender and other differences and have influenced changes in attitude and behaviour. However, participation is often framed narrowly as a methodology to improve project performance, rather than a process of fostering critical consciousness and decision making as the basis for active citizenship. Rarely is participation implemented as a mutual decision-making process, where different actors share power and set agendas jointly.

In addition to understanding participation as a methodology and decision-making process, a critical analysis of different spaces of participation is becoming increasingly important to building effective rights-based change strategies (Brock, Cornwall and Gaventa 2001). As a result of civil society pressure, opportunities for participation in policy discussions are opening up within powerful institutions such as the World Bank. However, when groups are invited to participate in these spaces, the agendas are often preset or circumscribed in ways that principally serve to legitimise the institution's prior goals and do not offer civil society real opportunities to engage on key policy questions. The distinctions between invited and claimed policy spaces are critical for making strategic choices about where and how to promote rights vis à vis formal institutions. Invited spaces include public discussion or policy-making processes, such as the World Bank's poverty reduction strategy processes, to which civil society groups are invited by powerful state and international actors who control the agenda and rules of engagement. In contrast, claimed spaces, such as citizen juries or public accountability sessions, are created by civil society organisations where the agenda and terms of debate and participation with state and international actors are defined by citizen's groups. Thus, beyond just a concern for the quality of participation, groups must also be alert to the nature of the spaces in which they are participating and to what extent they offer real opportunities for influence.

Ultimately, participation that advances more equitable development and rights seeks to:
- Include marginalised groups as protagonists and decision makers and foster their critical consciousness and ability to influence the norms, systems and institutions that affect their lives.

- Go beyond perfunctory consultations in externally imposed project and policy processes so that local groups can be involved in agendasetting, decision making and structures to hold government and donors accountable.

- Build new leadership, strengthen local organisation, expand strategic and political experience and foster a sense of active, informed citizenship.

- Change public decision-making structures and processes to be more inclusive of citizens' interests as well as promote individual and group awareness of rights.

- Unpack prevailing myths and assumptions about all "stakeholders" being equal and poor communities being homogeneous.

- Link rights efforts to concrete, relevant problems and solutions.

- Where needed, weave expert knowledge into community-designed strategies and analysis, so that groups can deal more effectively with the range of national and global institutions, forces and policies shaping their choices and livelihoods.

- Create and affirm a sense of individual empowerment, dignity and autonomy, as a basis from which to organise and engage with dominant forms of power and knowledge and to negotiate with existing power structures.

- Recognise the differences between the invited and claimed policy spaces of participation, so that communities, NGOs and other actors (including reformers within governments) can use their resources strategically to affect change rather than being diverted by agendas that have little relevance or impact.

\subsection{Rights}

Like participation, people understand rights in different ways. The concept often conjures up the image of a legalistic approach that is more technical than empowering. The legalistic approach to rights all too often focuses on "what-the-law-says" and downplays the dynamic aspect of the political process that shapes the extent to which rights are enforced and realised in people's daily lives (see Nyamu-Musembi, this issue). This legalistic view 
plays out in legal education efforts that essentially teach people (through workshops and pamphlets) a simplified version of laws and in advocacy efforts that focus exclusively on legal reform in order to "deliver rights".

The prevalence of legalistic approaches has contributed to a crisis in rights methodology evident in many of our interviews and through our work with rights organisations. While working with laws and legal systems is critical, it has become clear that narrow legal approaches usually fail to expand the scope of rights or appreciably strengthen accountability and capacity to deliver resources and justice. Equally important, these approaches do little to develop people's sense of themselves as citizens and subjects of rights, or their capacity to engage with and reshape power. Instead of starting with people's daily problems, rights groups usually use a discussion of law as an entry point into communities, failing to relate to how people experience the world and thus falling short of building active constituencies or sustained support for change. Good development practice emphasises the importance of starting where people are, a hardwon lesson that has not been part of many human rights groups' knowledge base or experience.

It's people who decide ... not human rights lawyers and the courts... The idea that we decide as a society [what constitutes rights] is the participation piece. And it is so important because it enables people to see their own role in history; enables ... [them] to know when their rights have been violated ... and that's the importance of participation ... because you can't build consensus [around rights] without participation. (Human rights advocate)

Women's rights activists helped call attention to the limitations of traditional human rights approaches that place the content of international laws at the heart of rights work, noting the importance of starting with an understanding of rights as a political process. Going beyond "what the law says", this understanding builds on a notion of rights as a work in progress that is forged and refined through social struggles. Some rights may exist on paper and when they do, the challenge lies in claiming them by engaging and reforming the structures and institutions charged with upholding them, and in expanding people's understanding of and sense of entitlement to rights (Schuler 1986 and 2002). Equally important are the efforts of individuals and communities to advance and expand rights not yet enshrined in law. This happens as people articulate and define their needs in rights language, gain acceptance of these rights and ensure that they are made real in people's lives, as exemplified by the global efforts of women's rights advocates to gain recognition of women's rights as human rights. In some situations, strategies and approaches that seek to build consensus and legitimacy about newly emerging rights are needed. This is particularly true with economic, social and cultural (ESC) rights. Realising ESC rights, for example, requires greater specificity in the content of the rights themselves and broader mobilisation to claim them, but also demands profound change in the structures and budget priorities of governments charged with addressing ESC rights.

Asserting rights, redressing injustice and accessing political and economic resources, requires using the system where possible and challenging and expanding it where necessary. The scope of recognised rights and the degree to which people can claim and exercise those rights, is forever shifting in response to shifting power dynamics. This appreciation allows for the identification of multiple entry points for action and the development of more holistic strategies that respond to the complexities of power and politics. Our colleagues working with social movements in Brazil (Pereira Júnior et al. 2004) and India (National Centre for Advocacy Studies 2004) who have been involved in this project name it quite clearly as 'a never-ending struggle, a life-long fight for rights'.

\subsection{Power and empowerment}

Questions of power and empowerment are at the heart of work on rights and participation, yet are not always understood in their full complexity. Indeed, many human rights and development initiatives reflect a linear or one-dimensional understanding of power. However, effective change strategies need to take into account that power operates dynamically at many levels to prevent people's participation and the fulfilment of their rights. Visible forms of power and decision making such as legislatures, laws and policies can discriminate against and undermine rights and participation of certain groups such as the poor and marginalised while hidden forces of power operate, 
often undetected, under the table to set the political agenda and benefit privileged sectors of society. These forces create systemic bias and exclude some sets of people and their issues from public consideration through different mechanisms, including by labelling their leaders as troublemakers and their demands as illegitimate or not appropriate for public debate. Invisible mechanisms of power are the most insidious because they shape meaning and notions of what is acceptable and who is worthy in society. They operate at a deeply psychological level to reinforce feelings of privilege or inferiority that, in turn, shape people's understanding of themselves, their world and their potential to act. Understanding and altering these power dynamics is critical to genuine participation and the fulfilment of rights (see also Lukes 1974; Gaventa 1980 and 1997; Kabeer 1994; VeneKlasen and Miller 2002).

Work on participation and rights is ultimately about challenging and transforming these types of power relations and creating new relationships based on values of solidarity, equity and the common good - a process that is often described as empowerment. Such efforts provide tools and create the conditions to help people expand their capacity to analyse problems and deal with power at the micro-level (personal, community and organisational) and macro-level (local, national and international policy arenas) as well as to develop alternative sources and forms of power that promote more equitable and healthy relationships (see Samuel 1999). Never easy, empowerment can be conflictual since it ideally questions and seeks to transform deeply embedded power relations from the most intimate to the most public and visible.

Empowerment has been used to describe a multitude of actions and, over the years, has been depoliticised, losing its initial emphasis on power and personal and political transformation. Thus, in conversations and strategising about rights and participation, definitions need to be clear to avoid misinterpretation. Srilatha Batliwala, a prominent Indian scholar and women's rights activist, provides a useful explanation:

The term empowerment refers to a range of activities from individual self-assertion to collective resistance, protest and mobilization that challenge basic power relations. For individuals and groups where class, caste, ethnicity and gender determine their access to resources and power, their empowerment begins when they not only recognize the systemic forces that oppress them, but act to change existing power relationships. Empowerment, therefore, is a process aimed at changing the nature and direction of systemic forces that marginalize women and other disadvantaged sectors in a given context.

Empowerment is not something done to people. Rather, it is a participatory process that engages people in reflection, inquiry and action. By sharing stories and doing a basic political analysis of common problems such as unemployment, violence, or inadequate health services, people can develop a clearer understanding of power. They begin to question their world and their place in it, affirming their own sources of power and discovering how power affects their lives positively and negatively. As they question, they develop and deepen a sense of personal worth, a critical and compassionate worldview and the skills and willingness to act both individually and collectively to improve their world. This change process not only involves developing political consciousness and an appreciation of rights, but also building new forms of inclusive power that forge bridges of solidarity and cooperation across differences such as ethnicity, class, gender and religion.

\section{Challenges in practice}

While many organisations have been making considerable investments in understanding how rights-based approaches can strengthen the impact of their work, taking these insights into practice is proving more difficult (see Hughes et al. this issue). As one development practitioner explained, 'Some of us feel versed in RBA [rights-based approaches] theory but less in how to operationalise it'. This section explores some of the key challenges that various civil society organisations face as they attempt to integrate rights and participation into their practice.

What makes a rights-based approach has to do with strategy and building relationships with communities ... and bringing together multiple fields to collaborate ... It's all about methodological approaches that make the link. It's not just about adding new content to your portfolio. (Development practitioner) 


\subsection{Distortion of language and meaning}

As noted above, there are multiple understandings of rights and participation (see Cornwall and Nyamu-Musembi, this issue). These notions tap into very deeply held beliefs and assumptions about democracy, citizenship, governance and power and for that reason, it is critical to recognise and explore the values, principles and practical significance of linking rights and participation. In the absence of this grounding, rights-based approaches are merely a new form of technical fix that combines expertdriven social and economic interventions with legal change that may not be relevant to people and communities or engage them as citizens. Yet huge challenges to this analysis are presented by circumstances in which concepts and language originally developed through social change efforts are co-opted, depoliticised and stripped of their original meaning (see Just Associates, ActionAid USA and the Participation Group at IDS 2001).

\subsection{Recovering a long-term vision of change}

In part, clarifying the conceptual and practical significance of rights and participation requires reconnecting and recovering a long-term vision of change. As human rights and development groups with a governance focus have concentrated on delivering technical outputs in short project timeframes (such as strengthened legislatures, law and constitutional reform, legal rights pamphlets and workshops), some staff complain they have lost sight of their vision of justice and social change. With that loss, the historical struggles that produced existing rights and the lessons that such struggles provide to current social change efforts have been overlooked. Similar concerns have been echoed by some women's rights organisations that question the value of focusing on the UN and legal outcomes to the neglect of organising and education work with women at grassroots levels. In the process of recovering and reconnecting to a long-term vision, people's assumptions about how change happens and how power operates, need to be surfaced since strategies are often based on unrealistic, onedimensional notions that do not address the realities of politics and power except at a superficial level.

\subsection{Facing contextual realities}

In many contexts, the rights framework and the notion of universal human rights is subject to intense criticism. Women's rights activists in the global
South have long found themselves on the defensive against allegations of being puppets of western feminists with little respect for local customs and traditions. As a result, many have found different language to use that is appropriate to their national context but challenges existing power structures and builds on the power of the universality of rights claims. They emphasise that in many cases, groups are not able to use the language of rights, but their practice is clearly from a perspective of rights-based approaches (Lumbantobing and Zulminarni 2004; Toyo et al. 2004).

At the same time, advocates are forced to reexamine and adjust their strategies for making claims on national and local governments at a time when the power of state structures is being weakened while some economic actors are gaining strength. This is a particularly critical concern for groups working on ESC rights who feel their demands for fulfilment of rights to basic services such as water or health care must compete with the pressure from international financial institutions to privatise those same services.

\subsection{Connecting the boxes}

For many development organisations, the process of integrating rights involves adding rights language and a legal or advocacy dimension to their work, rather than weaving together two distinct, but interconnected, approaches into a stronger whole. Increasingly, many groups seem to be embracing rights and policy advocacy for advancing systemic change, characterising "traditional" development and service delivery as simply treating symptoms of problems. In some cases, this is leading to the isolation and even the delegitimisation and defunding of some development programmes and counterparts. There is an unspoken assumption that "speaking on behalf of the voiceless" and thus, advancing rights for their local partners in policy spaces, will ensure better lives for the marginalised. This belief belies the crucial complementary role that development work performs in testing and crafting viable options to inequitable economic, social, political and cultural structures (not to mention addressing urgent felt needs), particularly at a time when strapped or corrupt governments cannot provide even the most basic of services. This perspective also risks overlooking the many innovative experiments in participatory and empowered approaches to decision making and 
local governance, often driven jointly by civil society groups and reform-minded actors within local governments. By failing to break down the boxes that have separated rights and development, nongovernmental organisations (NGOs) lose the potential dynamism and power that such integration offers.

Finding balance and synergy between these strategies and approaches will be fundamental to the success of change efforts. One way to understand their relationship more holistically is to view rights and advocacy as the political or policy side of participation and development efforts and to envision development and participation as the practical side of rights and advocacy work that gives rights concrete meaning in people's lives. Both rights and development practitioners point out that making the links between rights and participation will require adjustments in the pace of operations so that people have space to think and analyse these connections before they implement.

\subsection{Taking sides: whose rights count?}

The notion of rights as universal standards of human dignity belies their inherently political and conflictual nature. Rights do not come in neat packages, but rather are part of dynamic, sometimes messy, processes of resistance and change that work to engage and transform relations of power. Despite the existence of the international human rights system, the terrain of rights remains an everchanging, political arena where some groups' rights compete and conflict with others. The question of "whose rights count?" obliges rights and development groups to examine the values and forces of power that operate to exclude certain sectors of society while privileging others. The Washington Office on Latin America (WOLA) and ActionAid USA pose the question in their briefing paper on regional trade by asking whose rights take precedence - investor rights or peoples' rights? (Rowden and Gass 2004). In the case of trade, governments often find themselves squeezed between the opposing demands of their citizens and workers on one side and international corporate interests on the other. Thus, organisations find that rights-based approaches demand taking sides and they are not always prepared for the inevitable conflicts this can produce nor aware of the different arenas in which these conflicts occur.
Conflicts over whose rights count emerge at household and community levels as well, for example, where peasant rights groups reject efforts by women's rights activists to address violations that specifically impact women peasants; or, in the Niger Delta, where the local community believes it should benefit from the wealth of natural resources under its land, whereas citizens in other parts of the country demand that these resources benefit the entire country (see Jasis and García 2004; Toyo et al. 2004). Similarly, the actual process of claiming rights is often very messy and the rights that an individual claims depend on the particular institutional pathways (courts, village councils, etc.) he/she has access to. As a result, it is often the relatively richer and more powerful within a community who benefit from rights. Thus we see that the political context determines how competing rights claims are arbitrated at a local level.

Without a thoughtful analysis of these forces and dynamics at all levels of decision making and power, organisational strategies may turn out to be ineffectual or counterproductive and, in some cases, dangerous to those involved. Organisations therefore, need to be clear about how power operates in their contexts, what combination of strategies are most appropriate and what sources of support they can tap to mitigate and transform backlash and conflict.

\subsection{Organisational structures, fears and lack of flexibility}

Linking rights and participation involves not only strategic adjustments, but also organisational change. Yet the monumental shift in policy and discourse necessary for adopting a rights-based approach is, for a large organisation, a very slow, long process, requiring a sustained commitment of senior decision makers, as well as programme staff. Experience has shown that it can take more than ten years.

Many organisations have encountered considerable resistance among some staff who perceive rights-based approaches as too political. Common fears relate to the prospect of losing funders, public image, legal requirements and other risks. Some of these concerns have a certain basis in reality, for example US government funding is sensitive to language and political leanings and in many countries registration requirements or tax status of non-profit organisations does limit 
opportunities for direct advocacy. One human rights advocate working with funders in the USA explained the historical, cultural and ideological challenges in this way:

[there is a] rejection of the concept of any government obligation ... US culture is deeply individualistic with a strong belief in the selfmade man. There is a lot of sense of duty to others in our value-system but it's expressed through various types of social welfare. But as soon as you transform do-gooding into rights work, then forget it. It's too radical. (Human rights advocate)

A shift to rights-based approaches also may require different skill-sets among staff. For development organisations, this includes knowledge of rights, policy making and power dynamics as well as new approaches to strategic thinking and planning which are more attuned to structural inequalities and contextual dynamics. For rights groups, understanding power dynamics as well as adult learning theory and practice and community organising can be key to successful capacity-building with local counterparts.

Contemplating these challenges, one development practitioner remarked that it is 'so complicated to think of the implications for a massive bureaucracy that it's almost self-defeating'. Many international development and human rights organisations have been working in set ways for so long that the institutional inertia is hard to shake. Some staff point to the absence of space or willingness to be self-critical or creative. Some say that they do not know how to translate insights they receive from Southern partners into programming changes. Organisations with notable advances in linking rights and participation have invested in creating learning systems for capturing and integrating lessons from innovation and allowing space for some mistakes and learning by doing. This means overcoming time constraints, difficulties in finding effective methods, and resistance among some donors to support such processes.

\subsection{Addressing attitudes and roles}

Many organisations exploring rights-based approaches to development have found that they come up against difficult questions about how principles underlying rights and participation are reflected both within their organisations and in relationships with member or partner organisations. Power is not only an external foe that civil society organisations fight to transform. Internal power dynamics and structures can inhibit change within organisations. Similarly, unequal power relations between Northern and Southern NGOs can inhibit the kind of trust and effective partnerships necessary for linking rights and participation across borders.

Questions also arise about the role of Northern NGOs, especially when conflicts surface over strategies and resources. What is the relationship of the international organisation with the local NGOs and communities? ${ }^{2}$ Who sets the agenda? How are decisions made? In what direction does accountability flow and from where does the international organisation derive its legitimacy? While certain Northern groups recognise that many Southern organisations feel they are not real partners in agenda-setting or strategy development, awareness of these tensions has seldom translated into concrete institutional shifts toward participatory processes of consultation or joint decision making.

\section{Linking rights and participation: integrated change strategies}

Building shared understanding of the meaning and practical significance of linking rights and participation will continue over time. Organisations have encountered diverse challenges along the way and yet experience and research does highlight a few elements (discussed below) that are critical for effective rights-based approaches that link rights and participation.

\subsection{A power analysis that pushes beyond a basic mapping}

A power analysis that pushes beyond a basic mapping of formal structures and agendas of what is "on the table" to identify different interests and scrutinise the hidden and invisible dimensions of power under the table and their implications for action, is critical. By analysing the root causes of common problems, people can more easily clarify how dominant forms of power operate and they can begin to see how ideology functions to prevent the concerns and issues of marginalised groups from reaching public consciousness or gaining legitimacy. A deeper power analysis can explore how public 
power dynamics overlap with the personal spheres of family and self, the importance of which is well illustrated by the problem of HIV/AIDS. Many HIV/AIDS prevention activities and accompanying policy reforms emphasise condom distribution without considering how power in sexual relationships limit actual condom usage. Often, women say they are unable to negotiate condom use with their partners who either make light of the potential danger or accuse them of being unfaithful. As a result, the intended benefits of these policies and programmes are not realised. Empowerment strategies that emerge from this kind of analysis can help women and men to develop the courage, organisation and skills to confront such problems and forge more collaborative ways of using power.

\subsection{A focus on citizenship and organising as necessary complements of legal and policy change}

It is easy for organisations to get caught up in fastpaced advocacy and policy change agendas, giving short shrift to constituency-building and organising efforts that are in fact critical to sustain change on the ground. A focus on citizenship and organising implies that those most affected by the problems of poverty and discrimination must be at the forefront of setting agendas, planning strategies and taking action. It will also likely require negotiation with funders who ask to see signs of "empowerment" within a two-year project cycle. Balancing organising with policy work also demands a new understanding of the accompaniment role of NGOs as colleagues working in solidarity with movements and groups working with marginalised people in a long process of social transformation where both sides question and challenge one another. This approach and form of reciprocity can help NGO facilitators and organisers overcome an unintentional tendency to stifle critical thinking either by ignoring or romanticising grassroots knowledge. Rather than fostering paternalistic relationships, it encourages them to engage with counterparts in processes of mutual critique and learning in which both parties have expertise and negotiate agendas, resources and strategies.

\subsection{Clarity on the interaction among needs, rights and responsibilities}

Basic human needs and aspirations for survival and dignity are the impetus for rights and development struggles, which involve responsibilities of both people and states. The concept and obligation of rights move relationships beyond charity to justice. The fulfilment of rights and responsibilities depends in part upon the capacity of the state or other institutions charged with upholding rights to deliver on their obligation as well as upon the ability of citizens to exercise and claim rights. The daily challenge of meeting human needs for survival and dignity will always require struggle both to realise rights and, at the same time, to strengthen the institutional capacity of the state and civil society to protect, fulfil and enforce rights through accountable governance and community action and organisation. People are usually involved in these struggles and take on responsibilities when they believe their actions will address urgent needs. Thus the best starting point for community action and civic engagement is frequently an analysis of common problems and power relationships with rights presented as an important approach for solving problems and expanding and affirming citizenship.

\subsection{A broader understanding of identity and its application to strategy}

Personal identity is a place in which rights and participation intersect and can be both individual and collective. Each person has multiple identities, defined by race, gender, religion, class and age among other factors. In cases where identities have been the basis of discrimination, they can serve to activate people, helping them define their rights, gain confidence and a sense of community, and organise with others to act. However, to build bridges across differences and broader alliances for social change, people also need to reflect on values of solidarity and develop a more inclusive vision of society and the common good that go beyond the boundaries of their identity group. When rights of one group conflict with others, these differences must be negotiated as well. 
Rights-based Development: Linking Rights and Participation - Challenges in Thinking and Action

\section{Notes}

* Drawn from 'Rights based approaches and beyond: challenges of linking rights and participation', by Lisa VeneKlasen, Valerie Miller, Cindy Clark and Molly Reilly (2004), IDS Working Paper 234, Brighton: Institute of Development Studies. This article and the Working Paper it is based upon are part of a research initiative called 'Linking Rights and Participation', coordinated by the Participation Group at IDS and Just Associates (JASS), USA, in collaboration with country teams from Brazil, Mexico, Nigeria, Kenya, Zimbabwe, India and Indonesia. For more information see www.ids.ac.uk/ids/particip/ research/rights. This article draws on the outcomes of two international workshops, a review of relevant documents, a series of interviews with key US-based international actors, specifically groups working on human rights, development and democracy and governance. It also draws on the knowledge and insights of its writers gained through their experiences in work on development, rights, participation, power and empowerment over more than three decades, around the world. Absent from this analysis, however, is the important contribution that US social movements and labour unions make to bridging these ideas and strategies.

\section{References}

Brock, K., Cornwall, A. and Gaventa, J., 2001, 'Power, knowledge and political spaces in the framing of poverty policy', IDS Working Paper 143, Brighton: Institute of Development Studies

Gaventa, J., 1997, 'Citizen knowledge, citizen competence, and democracy building', The Good Society, Vol 5 No 3

Gaventa, J., 1980, Power and Powerlessness: Quiescence and Rebellion in an Appalachian Valley, Chicago: University of Illinois Press

Jasis, M. and García, M., 2004, Linking Rights and Participation: Mexico Country Study - Exploring the Relationship Between Human Rights and Citizen Participation, Brighton: Institute of Development Studies, www.ids.ac.uk/ids/particip/research/ rights/ (accessed December 2004)

Just Associates, ActionAid USA and the Participation Group at the Institute of Development Studies, 2001, Making Change Happen: Advocacy and Citizen Participation, www.ids.ac.uk/ids/particip/ workshops/makchhapstatm.pdf (accessed 14 July 2004)

Kabeer, N., 1994, Reversed Realities: Gender Hierarchies in Development Thought, London: Verso

Lukes, S., 1974, Power: A Radical View, London: Macmillan
1. Since the attacks of September 11th 2001, the launching of the US "War on Terror" and the Iraq war, some of these important gains in political rights and civil liberties are being eroded and violated in the USA as well as internationally. This has refocused the attention of many leading US human rights groups in returning to the question of political rights, lessening some of the energy and interest in ESC rights.

2. It is worth noting that many Southern NGOs operating as urban-based elite institutions often come under similar criticisms that they have little connection to the communities they claim to represent or benefit.

Lumbantobing, D. and Zulminarni, N., 2004, 'Linking rights and participation: Indonesia Country study', Brighton: Institute of Development Studies, www.ids.ac.uk/ids/particip/research/rights (accessed December 2004)

National Centre for Advocacy Studies, 2004, 'Linking rights and participation: Indian country study', Brighton: Institute of Development Studies, www.ids.ac.uk/ids/particip/research/ rights (accessed December 2004)

Pereira Júnior, A., Antunes M. and Romano, J.-O., 2004, 'Linking rights and participation: Brazilian country study', ActionAid Brazil and Brighton: Institute of Development Studies, www.ids.ac.uk/ ids/particip/research/rights (accessed December 2004)

Rowden, R. and Gass, V., 2004, Investor Rights or Human Rights? The Impacts of the FTAA, Washington, D.C.: ActionAid USA and Washington Office on Latin America

Samuel, J., 1999, What is People-Centred Advocacy?, Pune, India: National Centre for Advocacy Studies Schuler, M., 2002, Women's Human Rights Step by Step: Strategy Workbook, Washington, D.C.: Women, Law and Development International

Schuler, M., 1986, 'An Approach to Women, Law, and Development: Conceptualizing and Exploring Issues and Strategies', in M. Schuler 
IDS Bulletin 36.1 Developing Rights?

and L. VeneKlasen, Empowerment and the Law: Strategies of Third World Women, Washington, D.C.: OEF International

Toyo, N., with Nweze, C.C.J., Agary, K., Agary, T.K., Abdu, H. and Sadaet, I.N., 2004, 'Linking rights and participation: Nigeria country study: exploring experiences from the Niger Delta and
North West regions', Brighton: Institute of Development Studies, www.ids.ac.uk/ids/particip/ research/rights (accessed December 2004)

VeneKlasen, L. and Miller,V., 2002, A New Weave of Power People and Politics: The Action Guide for Advocacy and Citizen Participation, Oklahoma City: World Neighbors 